How to cite:

Erőss Á. (2017) Living memorial and frozen monuments:

the role of social practice in memorial sites

Urban Development Issues, vol. 55, pp. 19-32

DOI: 10.2478/udi-2018-0002

\#politics of commemoration

\#monument

\#memory

\#public space

\#social practice

\#Budapest

Ágnes Erőss

Geographical Institute

Research Centre for Astronomy

and Earth Sciences,

Hungarian Academy of Sciences

e-mail: eross.agnes@csfk.mta.hu

\section{Living memorial and frozen monuments: the role of social practice in memorial sites}

\section{Abstract}

Monuments and memorials have become mundane elements of public space: commemorative plaques, statues, and memorial sites are mushrooming in the wake of memory production. However, besides the emblematic ones that have become accepted both by the powers and the public, there is a long list of monuments which are less cherished and/or have failed to be accepted as landmarks. When analysing two memorials in Budapest, I was interested in the possible factors explaining the failure and/or neglect of a monument. The monument dedicated to the victims of the German Occupation of Hungary was never officially unveiled, thus has not become part of the governing authority's political landscape. Hence the proliferation of commemorative plaques on site the Corvin Passage, one of the emblematic scenes of 1956 revolution in Hungary, seems to be in a limbo between a commercial area and a heritage site. In contrast, the anti-monument on Liberty Square, a collage of personal relics, juxtaposing the official memorial, regularly visited by locals as well as tourists.

Based on the example of the anti-monument on Liberty square, I stress the importance of social practice in commemoration. I argue that a memorial site's public acceptance and success is correlated with its capacity to engage in regular social practices.

submitted: October 2017

reviewed: December 2017

accepted: February 2018

( 2017 Ágnes Erőss. This is an open access article licensed under the Creative Commons Attribution-NonCommercial-NoDerivs License (http://creativecommons.org/licenses/bync-nd/3.0/). 


\section{Introduction}

While monuments and memorials are as old as humanity, since the end of 19 th century memorials commemorating events and/or individuals of national importance have become essential elements of the landscape. Commemorative plaques, statues, memorials (Foote \& Azaryahu 2007) or street names (Azaryahu 1996a; Alderman 2003; Giraut \& Houssay-Holzschuch 2016) have a seemingly clear function: by placing a physical reminder in the public space they intend to enhance the recollection and integration of memories related to the subject of the commemoration and its narrative. Nevertheless, neither memory nor commemoration is a straightforward, simple, one-way road: both individual and collective memory is subject to constant reformulation, whereas a proliferation of commemorations and politics of remembrance explains why memorials have a difficult task when tempting to address the multiplicities of memories (if they wish to at all). Still, there are monuments, like the Arc de Triomphe in Paris, which have not only managed to survive various regimes, but if one considers the millions of tourists who visit it each year- can be declared a vivid monument transcending the grandeur of the nation and which are successful in engaging with people at the same time. However, there are monuments less appreciated, neglected, or even disdained by the public, or mistreated by a political regime. Such monuments can be considered as failures from the perspective of the power that installed them in order to advertise its narrative of the chosen event/ person. However, an unsuccessful monument might also be an overlooked chance in tourism (Boros 2017; Rátz, Smith \& Michalkó 2008) or urban heritage management (Shackely 1998, 2001).

The examples presented in this article intend to shed light on the role social practice plays in the 'life' of a monument. My major interest is to find possible reasons or explanations why a monument becomes unsuccessful or rejected? In the following, I stress the importance of social practice as a crucial element in the fate of a monument. I argue that public acceptance of a memorial largely hinges on whether it is capable of addressing and engaging with its visitors. This factor is dependent not only on the aesthetics of the piece of art, but on the message it broadcasts and the circumstances it was conceived in.

From the extensive geographical, multi- and interdisciplinary research tackling monuments and memorials from numerous perspectives, I refer to literature focusing on the nature of memory, the relationship between memory, place and social practice and the ways in which power interferes with memorialisation.

\section{Memory, (anti) monuments and commemoration}

Individual and collective memories are selective by nature: actual memory is constantly shaped or formed by one's expectations about the future, whilst certain elements from the past are selected and incorporated into that construction (Assmann 1995). Consequently, remembering and forgetting are inseparable: 'memories are crafted by oblivion' (Augé 2004: 20) which 'is a necessity both to society and to the individual' (Augé 2004: 3). In the constant dynamic flow of memory-(re)making spatiality can be perceived as a fixed, anchoring point. Memory is linked to a certain part of space procreating a meaningful place 'where various individual (and collective) projects converge and/or compete with other projects.' (Gustafson 2001:13). Nonetheless, every day practices legitimise places of remembrance: social actions transform a space into a place (De Certeau 2011), shape individual and community place identity (Proshansky, Fabian \& Kaminoff 1983) and engender attachment to places (Massey 1994; Ehrkamp 2005). Local traditions and urban legends make places alive and liveable, places one can go away from and return to (De Certeau 2011). The fate of such local histories and meaningful places they are linked to depends heavily on political decisions and policy actions (e.g. urban regeneration plans, development priorities) (Tölle 2010).

Taking into account that memory (both personal and collective) is selective and in constant reformulation, the endeavour to install a monument encapsulating the dynamism of memory and at the same time have capacity to engage with social practices seems quite a challenge. Hence, recognising the power lies in preselected memories which have taken physical shape and are installed in a public place, political regimes are usually eager to produce and control emblematic symbols and places by creating monuments (Meusburger, Heffernan \& Wunder 2011). A memory cast in stone, following a certain agen$\mathrm{da}$, eternalises one single narrative in a fixed aesthetic, serving specific purposes of the political power, limiting the freedom of remembering and forgetting. Therefore a monument contributes to the erosion of memory (Forty 2001): certain elements of the past become visible, whilst other details tend to remain obscured. In this sense, monuments and memorials play a similar role to mapping: they become tools in the hands of power to prove its existence (Erőss \& Tátrai 2016).

Such strong engagement with a specific political regime and its agenda explains why monuments have a risky life. On the one hand, a regime change is often followed by the demolition of the previous regime's political symbols (Harrison 1995; Verdery 1999; Foote, Tóth 
\& Árvay 2000). Secondly, to become a lieux de mémoire in Nora's (1989) term a monument requires live, regularly performed spatial practices. In other words, a statue remains a piece of art until it is embedded into the social practices of society. Performative acts like wreath-laying on national remembrance days in front of a monument, candle lighting at a war memorial or marching on Independence Day, can be comprehended as direct or indirect attempts by the powers-that-be to connect monuments with people's commemorative actions in the public space in order to implant new or redirect previously existing social practices. The role power plays in such practices is pinpointed by Maier: 'Commemorative effort is exquisitely political, hinging on the power of various constituencies to get their own memory publicly accepted' (Maier 1999: X). Thus, the fate of monuments is very dependent on how they are perceived, evaluated, accepted, neglected or even refused by the audience whom they intend to address. However, monuments have a very different power, potential and capability to become meaningful places or lieux de mémoire.

Monuments and the politics of commemoration have been a focus of scientific interest, including human geography, in recent decades. According to one, simple definition, a monument is built to 'induce remembrance of specific events or people' (Gregory et al. 2009: 478). Monument-building has been a hallmark of modern nationalism and the formation of modern nation states. A series of studies has thoroughly illustrated that monuments are employed by power to occupy public space in order to inscribe their specific narrative about the past, in many cases justifying its authority in the present (Nora 1989; Light et al. 2002; Till 1999; Hobsbawm 2015; Palonen 2008, Foote \& Azaryahu 2007; Rose-Redwood 2008). As J. Agnew and J. Duncan (1989: 7) put it, the memorial '[...] serves as a constantly re-energised repository of socially and politically relevant traditions and identity which serves to mediate between the everyday lives of individuals (...) and the national and supranational institutions which constrain and enable those lives.'

While in the 19th century heroic, figurative statues were preferred for celebrating national ideas and icons, in the late 20th century a major change can be detected in the artistic comprehension and design of monuments. More and more artists found that traditional monuments 'may only displace memory' reducing visitors to simple spectators instead of enhancing the work of remembering undertaken by individuals and society. That notion induced a proliferation of counter monuments - antiheroic in content, the figures rather conceptual - which can be understood as 'memorial spaces conceived to challenge the very premise of the monument' (Young 2000: 96).
Abstract aesthetics and non-traditional visualisation can also be detected in the case of national memorials, where anti-monumental design is perceived as more appropriate to challenge the traditional ideas of nation and to 'mark the national ambivalence and uncertainty of late twentieth-century postmodernism' (Young 2000: 93). As E. Strakosch (2010: 268) argues anti-monuments 'Instead of presenting a simple story of triumph or martyrdom, confront the nation-state with its own crimes and exclusions'. Alternative forms of commemoration show great variety and have resulted in the mushrooming of different terms, like counter, non-traditional or non-monument. In their thorough article, Q. Stevens, K. A. Frank and R. Fazakerley (2012) introduce a system to bring more clarity to the discussions. According to their opinion, on the one hand, monuments can adopt anti-monumental design whose aim is 'to express subjects and meanings not represented in the traditional monument' in any of five respects: subject, form, site, visitor experience and meaning. On the other hand, a monument can carry a dialogic message in which case it 'critiques the purpose and design of a specific, existing monument, in an explicit, contrary and proximate way' (Stevens et al. 2012: 952). The spatial position of a dialogic monument is also important, as it is often '(...) intentionally juxtaposed to another, pre-existing monument located nearby and that critically questions the values the pre-existing monument expresses' (Stevens et al. 2012: 962).

The act of memorialisation and practices of commemoration have also entered the everyday settings of life. As A. M. Shanken (2002: 132) described, so-called living memorials often take place in secular and utilitarian places ' (...) drawing memorialisation closer to leisure, recreation, and the desire for a cohesive community'. A flashmob in a public space can be understood as a living memorial, when a certain part of space becomes temporarily occupied by a - for instance - commemorative art performance.

To conclude, while a traditional monument is rather static and wishes to communicate straightforward messages, the major purpose of an anti-monument is to reject or renegotiate the original monument applying unconventional design, inviting visitors to use their senses to discover meanings and create their individual interpretation of the commemorated events or persons. Living memorials even move beyond: they use space as a mediator and stress the importance of social practice in remembrance.

\section{Corvin Passage:}

\section{a memorial site falling to oblivion}

Corvin Passage lies on the edge of the city centre, at the 
junction of two major traffic arteries (József Boulevard and Üllöi Road). It consists of a few blocks of houses surrounding a vast edifice of a cinema, being the most significant landmark in the lower middle-class residential neighbourhood. The rather uneventful life of Corvin Passage was instantly stirred when the Insurrection and War of Independence broke out in Budapest on 23rd October 1956. Due to its strategic location, Corvin Passage became the centre of the largest resistance group to combat the Red Army. Consisting mainly of youngsters, the insurgents of Corvin Passage, called 'the Boys of Pest' became one of the symbols of the 1956 Revolution. The revolution bestowed symbolic virtues on Corvin Passage such as activism for democracy, heroism and comradeship. The Insurrection only lasted a few weeks and its defeat was followed by years of terror and decades of oppression. The serious reprisals introduced by the Kádár regime silenced Hungarian society, making it impossible to openly commemorate the events. What is more, with the falsification or silencing of facts, Corvin Passage became deprived of positive associations: freedom fighters were labelled as bandits and enemies of (people's) democracy.

'Goulash communism' brought a 'relatively improved quality of life for a large proportion of society, if - in exchange - they showed a lack of interest in politics (Kovács 2001; Nadkarni 2003) and 'play-act' co-operatively, in accordance with the expected attitude towards the regime, in order to live a more fulfilling individual life (Yurchak 1997: 9). As a consequence of the policy of 'forgetting' imposed on society, a hiatus occurred in the memory of the place: the absence of a continuous presence of participants, survivors or other eyewitnesses of the events, local stories of the revolution have remained untold - even hidden from communicative memory. Lacking commemorative traditions and a loyal community willing to keep alive the memory of the revolution, Corvin Passage was not adopted as a site of commemoration in collective memory.

However, the 1956 insurrection became the reference point to the democratic transformation putting a peaceful end to socialism (Gyáni 2006). Erection of a large number of statues, monuments, and commemorative sites in the course of the following years signalled its symbolic importance. Owing to the emblematic role which Corvin Passage had played in the 1956 Insurrection, memorial tablets have gradually filled up the site. To date a total of 28 commemorative plaques have been placed in the narrow Passage, overwhelming majority on the external walls of the cinema. These tablets were installed by a few organisations, mainly congregating veterans declaring themselves heirs to the heritage of 1956. Except two (a Polish-Hungarian and an Eng-
lish-Hungarian) all are monolingual and none of them provides a general context or historiography of the events of Corvin Passage or the role the 'boys of Pest' played in it. Two categories of plaque can be differentiated: one is dedicated to general groups, like 'all the victims', 'all the heroes', and 'all the women'. The other group is comprised of plaques testifying to the individual heroism and glorification of the 'heroes' of the combat and 'victims' of the reprisal when referring to the people whose names are carved in stone. Notwithstanding, in some cases the accuracy of the inscribed data or its relevance to the site is questionable (Eörsi, L. 2009). Hence, all in all, the Corvin Passage with its manifold but generally uniform-looking black stone tablets gives the impression of a hallmark of fragmented, individualised testaments of persons whose stories remain untold. The fixed, static position of the commemorative plaques rather suggests the retaining of spatial distance rather than encouraging one to step closer. The placement of street furniture - facing the houses not the cinema wall - does not invite one to settle down and pay attention to the tablets (Photo 1).

Hence despite the mushrooming of commemorative plaques, Corvin Passage has not become a cult location, a historical pilgrimage destination in Budapest. Each year, between the 23rd of October and the 4th of November the Passage dresses up in ceremonial costume, flowers appear in front of the statue of a kid symbolising 'the boys of Pest', but commemorations only take place during the few official days of remembrance, while other practices or rites have not yet evolved to fill the space. The 60th Anniversary of the 1956 Insurrection in $2016 \mathrm{did}$ not bring new energies of commemoration to the place: one additional commemorative plaque was installed, but the official state level commemoration avoided Corvin Passage. However, the official commemoration campaign was dedicated to the topic of individual heroism featuring - among other individuals - important figures among the Corvin revolutionaries. The only commemorative ceremony was held by the right wing opposition Jobbik party. As a telling symbol of the contradictory commemoration of Corvin Passage, a poster depicting revolutionaries in the entrance to Corvin Passage needs to be mentioned: while it had been on display from late June, it disappeared few weeks prior to the official remembrance day, 23rd October (Photo 2).

One driving force of the regeneration of the memory of 1956 was that it actually enhanced forgetting by remembering: building a monument in a way exempts both society and individuals to engage in the real work of remembering and the donning of a heavy burden of responsibility (Young 1993). The removal of visible signs of the socialist heritage (street names, statues etc.) from 

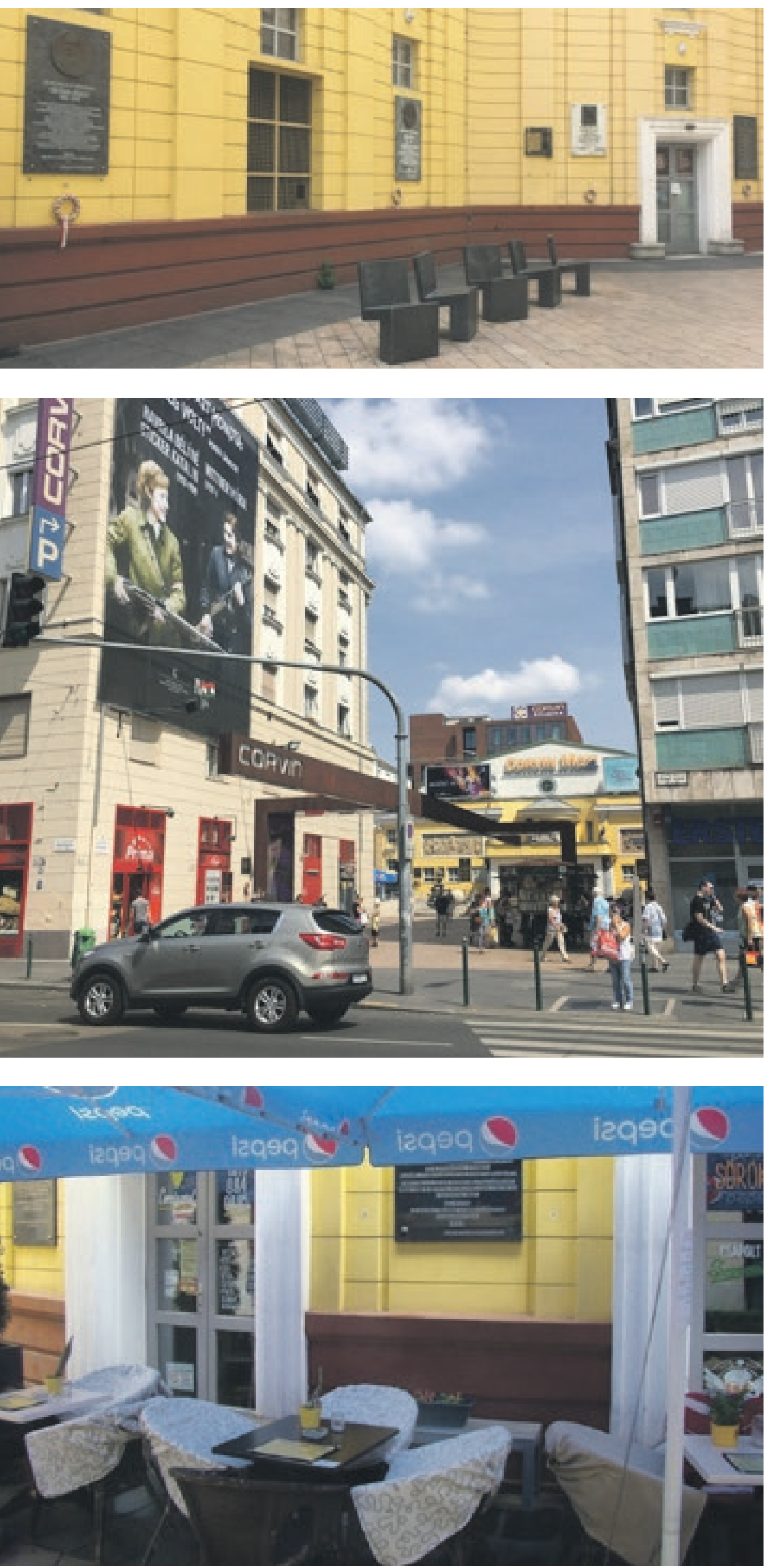

Stone chairs present their backs to the commemorative plaques

Source: Â. Erőss

\section{Рното 2}

The entrance of the Corvin Passage in July 2016: a poster celebrating revolutionaries was removed a few weeks prior to the 60 th anniversary

Source: Á. Erőss

Corvin Passage between pathos and the mundane: a commemorative plaque covered by the sunshade of a cafe.

Source: G. Michalkó 
the urban landscape in the early 1990s to some extent cleansed individual memories of those who had been complicit with the regime. On the other hand, having seen the rivalry among the organisations of 1956 and political parties' constant attempts to expropriate the legacy of the revolution, society in general has lost interest in 1956. The memory work of individuals and society as a whole has not taken place, rather disillusionment became general.

Not only local people or wider society, but politics also seems to tiptoe around the revolutionary heritage of Corvin Passage. In 2011 the Hungarian Government pronounced Corvin Passage a historic heritage site ${ }^{1}$, but the New Public Cemetery (located in a peripheral district of Budapest, Rákoskeresztúr) where - among others the martyrs of the revolution were buried, was declared a national memorial by the Hungarian Parliament, the latter thus gaining a higher level of recognition in the official politics of memory. Through the legislature, Hungarian state policy confirmed the importance of Corvin Passage as a historic site, but in the actual narrative of the anti-communist revolution, the political victims of show trials occupy a more prominent position than the 'the boys of Pest'. Consequently, the centre of the annual commemoration was gradually transferred from the centrally located Corvin Passage to the periphery of Budapest, the New Public Cemetery of Rákoskeresztúr (Erőss, Michalkó \& Galambos 2016).

However, besides the politics of forgetting in the Kádár era and the fragmented memory and remembrance of 1956 following 1990, one should take into account the effect of post-socialist urban transformation that might limit the evolution of the memorial site. The fall of the Iron curtain induced dramatic shifts in post-socialist cities: they had to face serious damage derived from the collapse of the political and economic system while at the same time the rapidly developing global economy imposed urgent demands and decisions (Tölle 2010). The appearance of Corvin Passage, and additionally the streets lying behind it, has been considerably transformed in the last ten years. As part of a massive urban rehabilitation project, a shopping mall and dozens of newly built residential blocks were erected right behind Corvin Passage attracting rather youth and foreigner population (Boros et al. 2016). The narrow Corvin Passage mainly serves as a commercial zone: the cinema, cafes and shops inviting thousands of visitors every day, who pass by or sit by the memo-

1. 303/2011. (XII. 23.) Government Decree on Historical Commemorative Sites rials covered by sunshades (Photo 3). The message of Corvin Passage, as it is sculpted and fixed to the walls of the cinema, most probably fail to reach the rapidly changing local community and visitors contributing to the gradual fading away of local history. The case of Corvin Passage highlights that 'a sacred place is a scarce commodity' (Kovács 2001: 75): Profane places with mundane functions (such as Corvin Passage) are difficult to transform into places of commemoration.

\section{The neglected monument dedicated to the victims of the German occupation in Liberty Square}

In an opposite scenario to Corvin Passage, Liberty Square has been one of the most important symbolic spaces in the modern history of Hungary. Situated in the heart of Budapest, only a few steps from the Parliament, the Square is surrounded by grandiose palaces housing, among other bodies, the Hungarian National Bank, the offices of international companies, and governmental institutions. The square has been the subject of a series of symbolic space appropriation campaigns carried out by consecutive political powers over the last two hundred years (Zeidler 2007). As a result of symbolic political manoeuvres, today the square is packed with historically-politically engaged monuments, spatial mnemonics of different regimes: for instance the monument dedicated to the Soviet soldiers who lost their lives while 'liberating' the city at the end of WW2 stands between the statue of Ronald Reagan and the US Embassy (Fig 1). Memories of mass-protests in support of different political ideas and powers juxtapose various narratives of freedom and notions of liberty.

The latest monument was installed in the southern part of the square in 2014. The government decree about the erection of the monument dedicated to the victims of the German Occupation of Hungary during the WW2 was issued on 31st December 2013. There instantly erupted intensive national and international objection which only slowed down the construction: two days after the victory of the governing party (Fidesz) in the parliamentary elections, construction restarted (Fehér 2014). Eventually the last pieces of the monument were put in place on 20th July, a Saturday night (Nolan 2014).

The final version of the monument was condemned by professionals and the public audience. The critiques presented concerned three major points. First, the spatial location is simply not suited to a memorial. The monument (designed to only face in one direction, the south) is placed on the south side of Liberty Square, squeezed in 
between the service road of an underground garage and a narrow road with constant one-way, car traffic (Photo 4). The unfortunate position impedes potential visitors who would wish to stand close to it, while stepping back is also not the best option, as a fountain is operating at the south end of the square almost all year around, which partially blocks the view and definitely attracts the attention of visitors.

The second point of critique concerned the aesthetics. As the respected sculptor, György Jovánovics summarised: 'This is not an up-to-date work. (...) Viennese neo-baroque mixed with social realist kitsch (Földes 2014). The composition adopts easy to decode figures, but the comprehension is further enhanced by inscriptions (Photo 5). Such a didactic design in public art is rather out-dated: since the 1970s and 80s non-figurative compositions have frequently been used in public sculptures and also monuments as well (Young 2000).

Nevertheless, both aforementioned concerns were dwarfed by the outcry over its message and the symbols that were chosen to depict the narrative. According to the objections, the interpretation of the monument relativises the responsibility of the then Hungarian government and armed forces which assisted in the extermination of nearly half a million Hungarian Jews during the Holocaust (Ungváry 2014; Pethő 2014). As historian K. Ungváry commented: the monument's symbolism (i.e. depicting Hungary as Archangel Gabriel who was attacked by Germany represented by the imperial eagle), and the political intention behind it, tries to 'whitewash' Hungary's role in the Jewish Holocaust in Hungary (Ungváry 2014).

Notably the monument has never been officially inaugurated and it has never been used in any official ceremony or commemorative event. Consequently, it has not become part of the symbolic landscape of the authorities, neither was it accepted as a monument or memorial by the public. Thus if we accept the definition of a monument discussed in the previous chapter, the Liberty Square monument exemplifies an unsuccessful attempt at commemoration.

\section{The anti-monument in Liberty Square}

Unlike the aforementioned monument, a narrow section of the pavement in front of it is not neglected: a juxtaposed anti-monument occupies it as a tangible, materialised form of protest. The anti-monument, named Living Memorial (Eleven Emlékmü), was established on 23rd March when a flashmob, entitled 'Living memorial-my history' was organised by artists, philosophers, sociologists, curators, and civic activists. Attendees were asked to bring items, reminders of their or their families' history, traumas suffered during the period of the German Occupation of Hungary. The first personal artefacts were placed in front of the construction site. During construction hours activists collected and stored them in a safe place, but every afternoon the anti-monument appeared on the pavement and remained during the night. Since the completion of the monument in July 2014, the anti-monument on Liberty Square has become a fixture of the cityscape: the items are distributed on a 20-50 centimetre wide section of the pavement facing the official monument (Photo 6).

It is an ever-evolving composition made up of personal relics, like family photos, hand-written family stories, eviction notices, personal belongings, stones (some indicating the date and place when and from where the given person/family was transported to a concentration camp) (Photo 7).

Next to the personal relics, two white chairs are an essential part of the counter-monument. According to the intention of the creators (among many others: György Jovánovics, András Rényi, Balázs Horváth, Szabolcs KissPál) the chairs facing each other are invitations for discussion: anybody is welcome to enter the discussion about the monument, the protest or that part of history (Hegyi 2015: 84-85) (Photo 8).

Holocaust survivors and their relatives shared memories during the daily events, joined by historians, artists or activists. The major point was to open a discussion, a discussion which had not happened before the construction of the monument. Thus, the purpose of the counter-monument was to offer a narrative of the history of the German occupation different from that represented by the state monument.

In fact, the anti-monument is an ever-changing assemblage of printed and hand-written papers, inscribed stones, photos, and two chairs. Furthermore, the counter-monument is enriched with plants and flowers which can be comprehended as metaphors for life and the living. Daily routines like watering and nurturing the plants or lighting candles can be considered as activities to keep the memory alive, just as the Living Memorial itself. Also, as M. Azaryahu (1996: 507) noted in the case of Kikar Rabin in Tel Aviv, ritual activities might contribute to the institutionalisation of the unofficial memory site.

This is in stark contrast to the static character of the state monument and its version of frozen memory; cast in stone, the monument is rigid in form and oblivious to personal and familial memories.

The counter-monument challenges the official monument with its content/message and also with its aesthetics. By showing personal items, letters, family photos it brings the focus to the individual perspective of the 


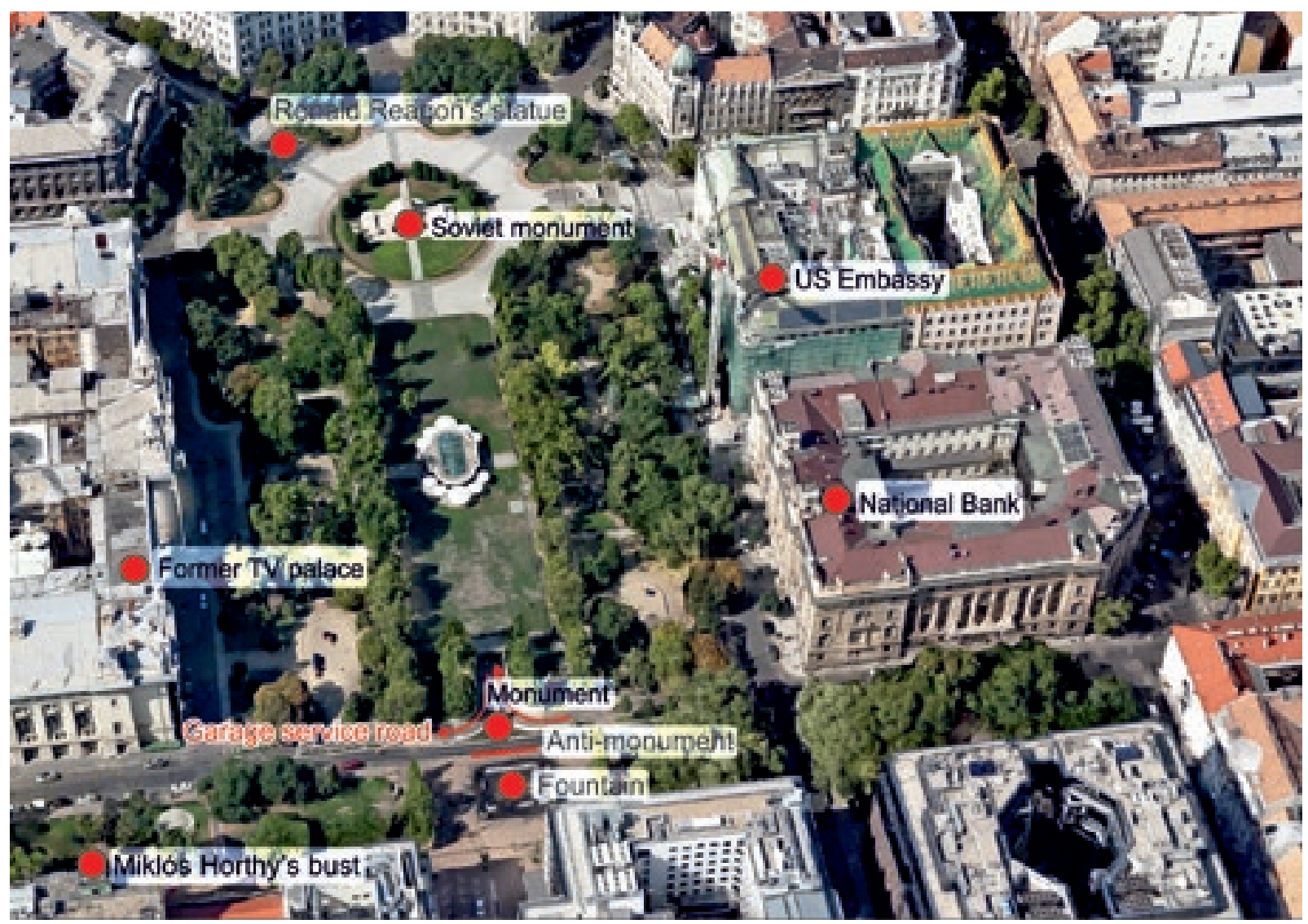

FIGURE 1

Overview of Liberty square (Szabadság tér), Budapest

Source: Eross 2016: 238 events clearly challenging and thus subverting the authority of the official monument. Regarding the aesthetics the official monument applies simplistic symbolisation and conventional metaphors (e.g. angel, eagle) while the family memories, diaries, personal belongings serve as unique testaments, inviting the visitor to spend time there and engage with the items. Furthermore, the counter-monument is in constant motion: anyone can touch and add new pieces or leave messages. The tangible character further stresses the striking difference from the official monument which stands on the other side of the road oddly squeezed in a tiny spot, impossible to touch, or even step close to. Moreover, the Living Memorial is not only alive because of the personal items and flowers it includes: it has a personality, as activists are ready to inform or start a conversation about the monument and the protest with visitors, including foreigners: a short description of the protest is available on the spot in the English, German, Hebrew, Russian, French, Spanish, Portuguese and Hungarian languages. This explains why the anti-monument is on the route of guided tours and visited by individual travellers as well (Photo 9).

It is important to highlight that the protest not only gave birth to the anti-monument: civil groups grown out of the protest are regularly present on the activist scene in Budapest as well. One group, called 'Living Memorial - My history', organises public discussions on topics such as the politics of memory, actual politics or social issues. The activity of the Freedom Stage (Szabadság Színpad) rather focuses on taking care of the anti-monument (Photo 10) but they also arrange cultural and commemorative events (Hegyi 2015: 87) (Photo 11). Both groups are engaged in civic activism and charity. For instance they commemorated the 100th anniversary of the Armenian Genocide, organised donations to refugees in the summer of 2015 or have joined numerous other protests ever since. 

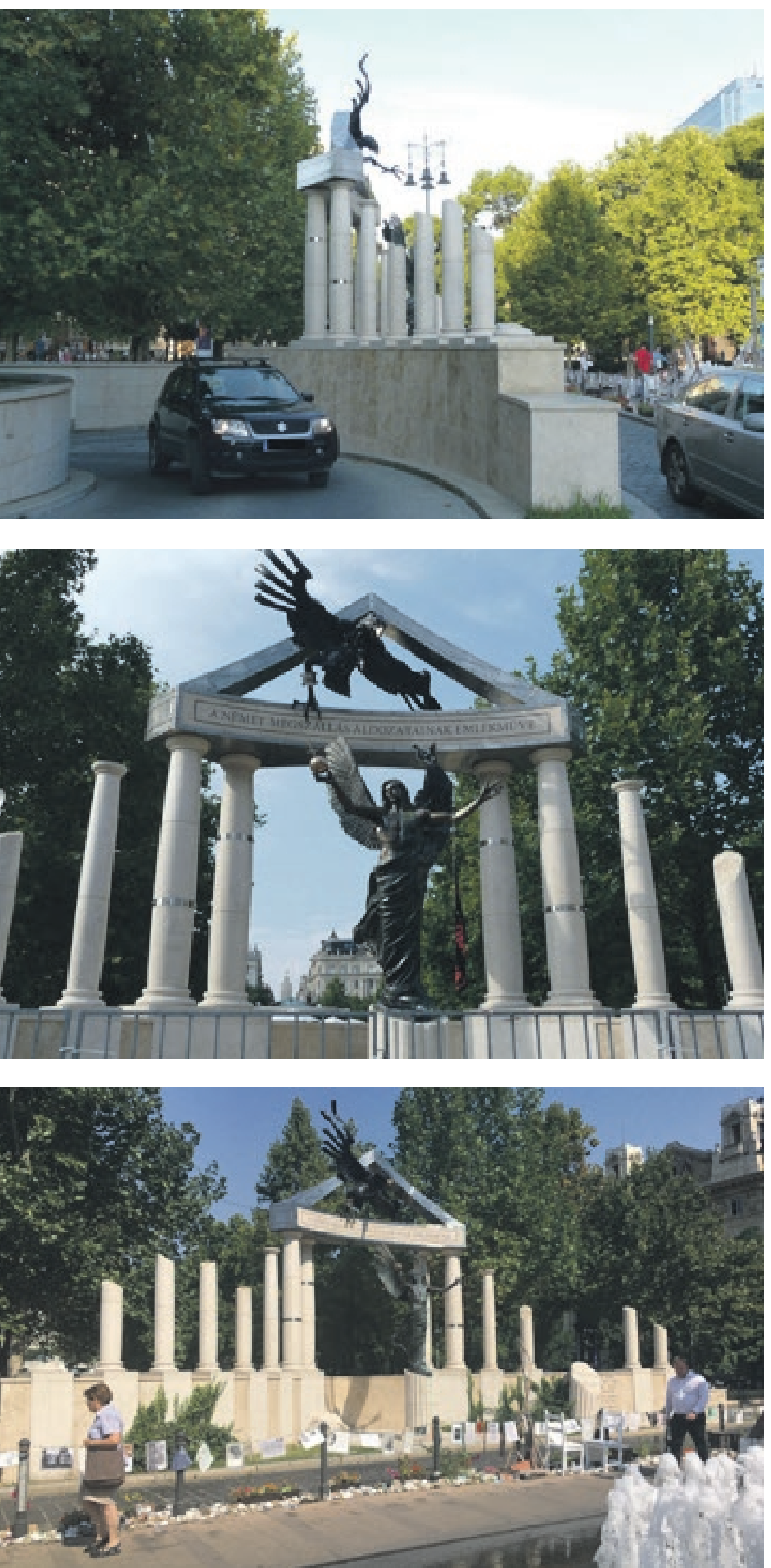

РнOTO 4

The Liberty Square monument standing on a little piece of land, squeezed in between roads

Source: Á. Erőss

\section{PHOTO 5}

Figures of the Monument dedicated to

the victims of the German occupation of Hungary

Source: Á. Erőss Source: Á. Eröss

The spatial position of the memorials in Liberty square: in the background the official monument, on the pavement the 
Altogether, the Living Memorial on Liberty Square can be perceived as a satisfactory example of an anti-monument: while the official monument is a clichéd, artistically out-dated composition, installed as a result of a top-down political decision, the juxtaposed Living Memorial - compiled from constantly enriched relics - has a human, personal, and tangible character. The memorial born as a result of a bottom-up initiative, due to narratives broadcast by the individual stories of those commemorated, invites one to interact and creates a connection between the past and the present (which should be one of the major purposes of any monument) strengthened by the presence of activists. All in all, it is not a neglected monument but rather the anti-monument is the one that induces remembrance. Taking into account the regular activities of the civil population maintaining it and the presence of local residents and tourists visiting it day by day, it can be stated that the anti-monument is way more successful in engaging with visitors and engender acts of remembrance of many. Consequently, apart from functioning as a memorial by definition, it can also be considered a successful memorial.

\section{Conclusion}

Analysing memorial sites in Budapest, the present paper's objective was to better understand the factors determining the fate of a monument, whether it becomes accepted, neglected or mistreated by the public. If we accept R. S. Nelson and M. Olin's argument, a monument's social relevance and vitality is correlated with its capacity 'to coalesce communal memories and aspirations' (Nelson \& Olin 2003: 6), I argue that both the state-financed monument dedicated to the victims of the German occupation in Liberty Square and the memorial site of Corvin Passage are failures.

Corvin Passage, an important scene of the 1956 Insurgency in Hungary, lies in a delicate limbo between fulfilling its functions as a heritage site and as an everyday public living space. It illustrates what we might term the dichotomy which derives from, on the one hand, the policy of forgetting which was cultivated by the leaders of the one-party state before 1989 and, on the other hand, the rival commemorative policy which has evolved since 1990 and which itself is deeply embedded in current political power struggles. Various divisions between NGOs and associations dedicated to the commemoration of the revolution resulting in, for instance, a great number of commemorative plaques placed in the Passage. As a second factor the ruptures in the collective memory of the space needs to be mentioned. Since the defeat of the revolution was followed by serious reprisals, Hungarian society was silenced, thus local histories and figures could not appear even in the communicative memories. Recently, chiefly as a consequence of an extensive urban rehabilitation project, the composition of the local population has significantly changed, but the memorial site is failing to address the increased number of daily visitors. Finally, owing to a lack of site management (Irimiás 2014), active commemoration is almost exclusively concentrated in a short period of official events, whilst on all other days of the year mundane, everyday activity dominates the public space.

The composition dedicated to the victims of the German occupation on Liberty Square, besides its weird and utterly unfortunate spatial position and highly questionable aesthetic value, represents a narrative which is not only misguiding, but is based on dubious interpretations of the past. Instead of opening a discussion in order to come to terms with the traumas the nation went through in WW2, it represents a blurred vision of victimhood, without the intention of practicing self-criticism and exempts the state from its responsibility, further procrastinating public discussion and the work of memory. While some commemorative events take place in Corvin Passage, the Liberty Square monument failed to become part of the political landscape of power: no official ceremony ever took place in front of it.

As a striking contrast to the aforementioned examples the third memorial site presented, the anti-monument on Liberty square stands as a testament of victims, a collage of personal relics. Instead of offering blurred, misleading narratives delivered in an out-dated artistic design, it invites visitors to step close, to read information about the historical context, to familiarise themselves with the events and the family related personal memories. It embodies what is missing from the above two memorial sites: it is accessible, tangible, alive and dynamic. Furthermore, the presence of activists, and the regular events organised there, the anti-monument managed to engage in the social practices of people, instilling the monument with life. Lighting candles, replacing the damaged inscriptions on the anti-monument, arranging black and white chairs in a circle to host public talks or taking photos of it when visiting Budapest; all these activities require social and spatial activities and interactions with the monument. Acknowledging the importance of social practices in creating places (De Certeau 2011) and turning a monument into a meaningful place, a lieux de mémoire which is able to conflate and symbolise diverse narratives of historical events, the anti-monument is the one that seems to be the successful memorial.

Finally, I would like to pinpoint the paradoxical relationship between the Liberty square monument and the anti-monument. Even though the original 


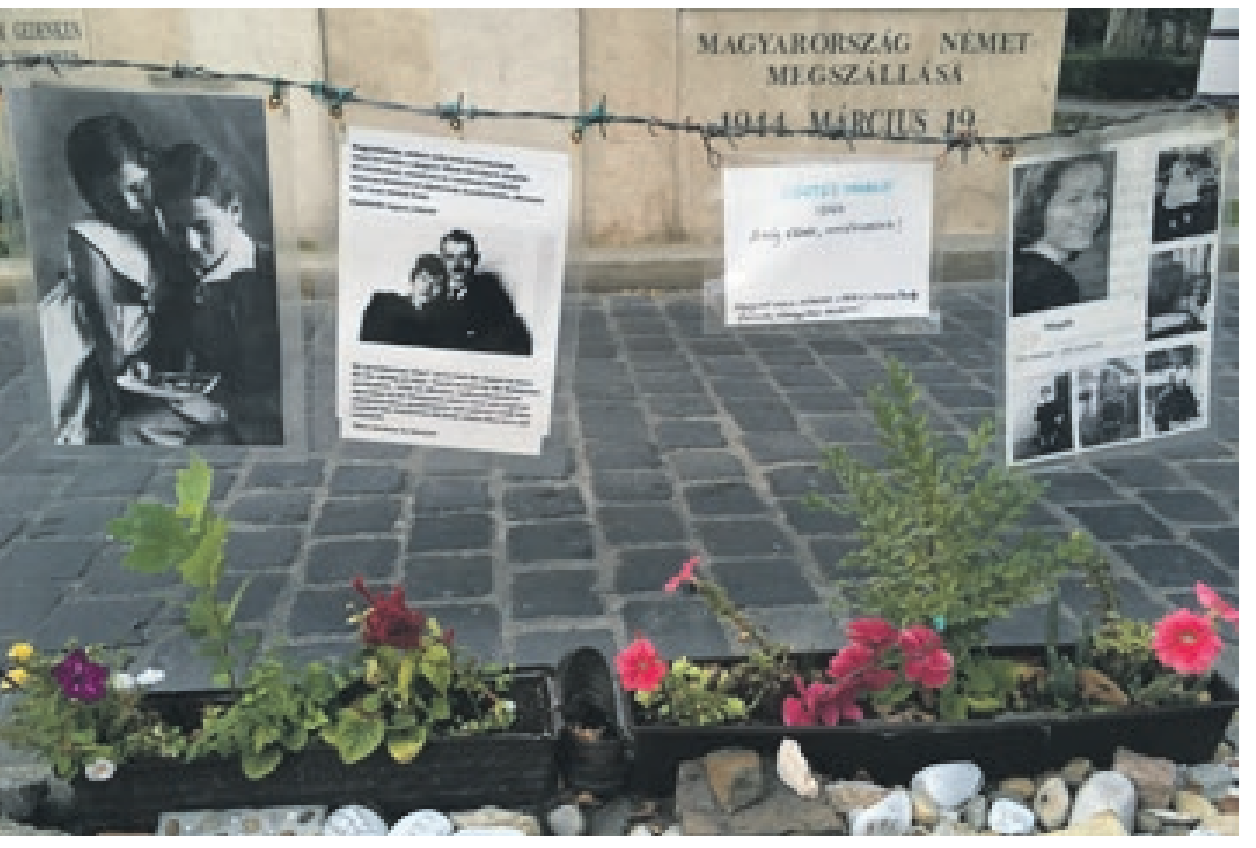

РнОто 7

The anti-monument compiled from personal relics, photos, photo copies of eviction notices, hand written texts, messages,

flowers, stones, etc.

Source: Á. Erőss

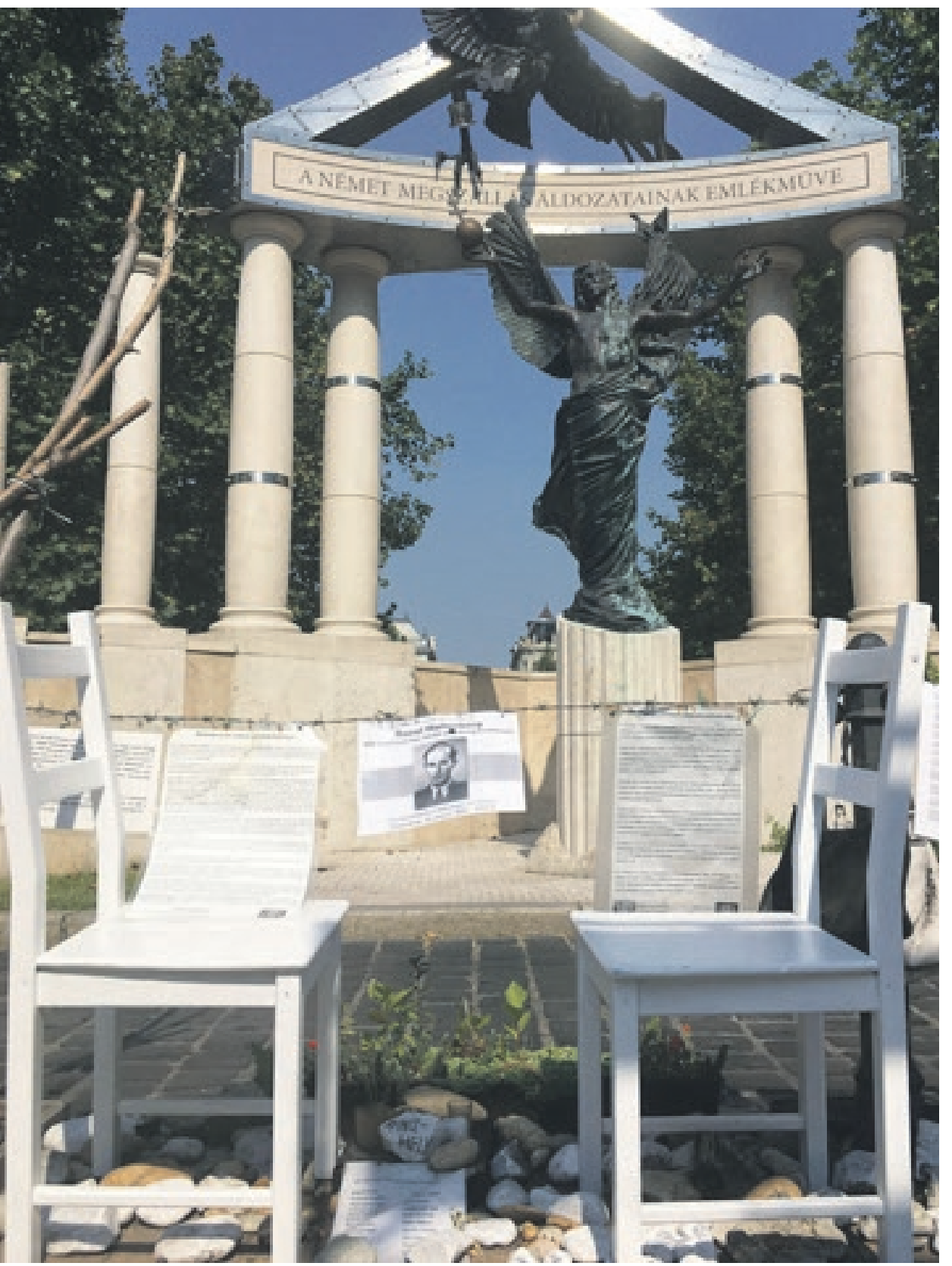

Рното 8

Two white chairs in the installation inviting discussion

Source: Á. Erőss 
Рното 9

Visitors to the anti-monument

Source: Á. Erőss
Рното 10

Small repairs carried out by activists on the anti-monument

约 $\quad$ Source: Á. Eröss

Рното 11

One of the regular afternoon events of the activists of Freedom Stage

Source: Á. Erőss
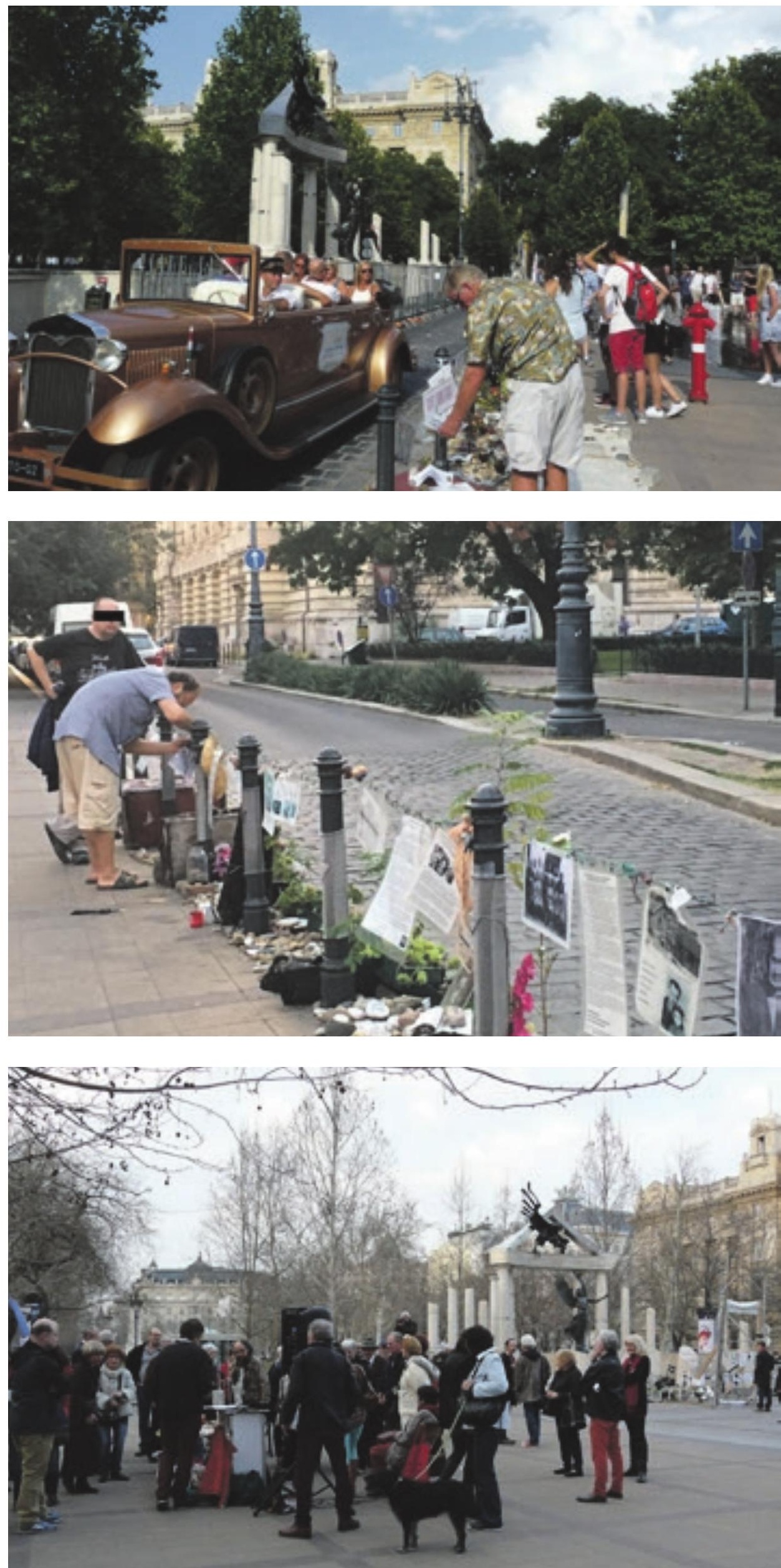
purpose of the activists was to prevent the construction of the monument, it is actually the existence of the anti-monument which justifies the presence of the monument. In other words, the anti-monument is the one that keeps alive/protects the official monument from oblivion (Erőss 2016).

\section{REFERENCES}

Agnew, J. \& Duncan, J., eds., (1989) The Power of Place: Bringing Together the Geographical and Sociological Imaginations, Unwin Hyman, Boston.

Alderman, D. (2003) Street names and the scaling of memory: The politics of commemorating Martin Luther King, Jr within the African American Community, Area, 35(2), 163-173. DOI: $10.1111 / 1475-4762.00250$

Assmann J. (1995) Collective memory and cultural identity, New German Critique, 65, 125-133. DOI: 10.2307/488538

Augé M. (2004) Oblivion, University of Minnesota Press, Minneapolis.

Azaryahu, M. (1996a) The Power of commemorative Street Names. Environment and Planning D: Society and Space, 14 (3), 311-330.

Azaryahu, M. (1996b) The Spontaneous Formation of Memorial Space. The Case of Kikar Rabin, Tel Aviv, Area, 28( 4), 501-513.

Boros, L. Fabula, Sz. Horváth, D. \& Kovács, Z. (2016) Urban diversity and the production of public space in Budapest, Hungarian

Geographical Bulletin, 65 (3), 209-224. DOI: 10.15201/hungeobull.65.3.1

Boros L. (2017) A közterek átalakulása és a turizmus, [in:] G. Régi, T. Rátz \& G. Michalkó, G., eds., Turizmus és transzformáció, Kodolányi János Főiskola, MTA CSFK Földrajztudományi Intézet Magyar Földrajzi Társaság, Orosháza, Budapest, 131-149. [in Hungarian]. Available from: http://real.mtak.hu/id/eprint/54051 [accessed: 22.10.2017]

De Certeau, M. (2011) The practice of everyday life, University of California Press, Berkeley, Los Angeles, London.

Ehrkamp, P. (2005) Placing identities: Transnational Practices and local attachments of Turkish immigrants in Germany, Journal of Ethnic and Migration Studies, 31(2), 345-364.

Eörsi, L. (2009) A Corvin közi emléktáblák. [in Hungarian]. Available from: http://www.historia.hu/userfiles/files/2009-0910/Eorsi. pdf [accessed: 10.08.2014]

Erőss, Á., Michalkó, G., Galambos, I. (2016) Pathos and the mundane in the symbolic space of 1956 revolution: the case of Corvin-passage, Budapest. Almatourism: Journal of Tourism, Cultura and Territorial Development, 7 (5), 44-60. DOI: 10.6092/ issn.2036-5195/6381

Erőss, Á. \& Tátrai, P. (2016) When reality meets power/rhetoric. Power, mapping and practice in contested spaces: the case of Cyprus and Karabakh, Documenti Geografici, 2016(1), 1-30. DOI: 10.19246/docugeo2281-7549/201601_01

Erőss, Á. (2016) "In memory of victims": Monument and counter-monument in Liberty Square, Budapest, Hungarian Geographical Bulletin, 65(3), 237-254. DOI: 10.15201/hungeobull.65.3.3

Fehér, M., 22.09.2014, US Urges Dialogue on Hungary’s Controversial Nazi Occupation Monument. Available from: http://blogs. wsj.com/emergingeurope/2014/04/22/us-urges-dialogue-on-hungarys-controversial-nazi-occupation-monument/ [accessed: 10.08.2014]
Foote, K., \& Azaryahu, M. (2007) Toward a Geography of memory: Geographical dimensions of public memory and commemoration, Journal of Political and Military Sociology, 35(1), 125-144.

Foote, K. Tóth, A. \& Árvay, A. (2000) Hungary after 1989: Inscribing a new past on place. The Geographical review, 90(3), 301-334. 10.1111/j.1931-0846.2000.tb00340.x

Földes, A., 21.11.2014, A megszállási emlékmü: köztéri merénylet. Available from: http://index.hu/belfold/2014/01/21/rohamtempoban_keszul_a_nemet_megszallasi_emlekmu/ [accessed: 10.08.2014] [in Hungarian].

Giraut, F. \& Houssay-Holzschuch, M. (2016) Place Naming as Dispositif: Toward a Theoretical Framework, Geopolitics, 21 (1) DOI: 10.1080/14650045.2015.1134493

Gregory, D., Johnston, R., Pratt, G., Watts, M. \& Whatmore, S., eds., (2009) The Dictionary of Human Geography, 5th Edition. Wiley-Blackwell

Gustafson, P. (2001) Meanings of places: everyday experience and theoretical conceptualizations, Journal of Environmental Psychology, 21, 5-16. DOI: 10.1006/jevp.2000.0185

Gyáni, G. (2006) Memory and Discourse on the 1956 Hungarian Revolution. Europe-Asia Studies 58(8), 1199-1208. DOI: 10.1080/09668130600995731

Harrison, S. (1995) Four types of symbolic conflict. The Journal of the Royal Anthropological Institute, 1(2), 255-272. DOI: $10.2307 / 3034688$

Hegyi, D. (2015) Turning a non-place into a place: An interview by Dóra Hegyi with members of the Living Memorial, [in:] D. Hegyi, Zs. László \& Zs. Leposa, eds., War of memories. A guide to Hungarian memory politics, Tranzit.hu, Budapest, 79-104.

Hobsbawm, E. (2015) Introduction: Inventing traditions, [in:] E. Hobsbawm \& T. Ranger, eds., The Invention of Tradition, eds., Cambridge University Press, Cambridge, 1-14.

Irimiás, A. (2014) The Great War heritage site management in Trentino, northern Italy, Journal of Heritage Tourism, 9(4), 317-331. DOI: 10.1080/1743873X.2014.908886.

Kovács, É. (2001) A terek és a szobrok emlékezete (1988-1990) Etűd a magyar rendszerváltó mítoszokról, Regio, 12(1), 68-91 [in Hungarian].

Light, D., Nicolae, I., \& Suditu, B. (2002) Toponymy and the Communist City: Street name in Bucharest, 1948-1965, GeoJournal, 56 (2), 135-144.

Maier, Ch. S. (1999): Preface, [in:] P. G. Abir-Am \& C. A. Elliot, eds., Commemorative Practices in Science: Historical Perspectives on the Politics of Collective Memory (Osiris, 14), The University of Chicago Press, Chicago, IX-XII. Available from: http://www.jstor. org/stable/301958 [accessed: 10.02.2018].

Massey, D. (1994) Space, place and gender, University of Minnesota Press, Minneapolis.

Till, K. (1999) Staging the Past: Landscape designs, cultural identity and Erinnerungspolitik at Berlin's Neue Wache, Cultural Geographies, 6 (3), 251-283. DOI: 10.1177/096746089900600302. 
Meusburger, P., Heffernan, M., \& Wunder, E., eds. (2011) Cultural memories. The geographical point of view, Springer, Heidelberg.

Nadkarni, M. (2003) The death of socialism and the afterlife of its monuments. Making and marketing the past in Budapest's Statue Park Museum, [in:] K. Hodgkin \& S. Radstone, eds., Contested pasts. The politics of memory, Routledge, London, 193-207.

Nelson, R.S. \& Olin, M. (2003) Introduction, [in:] R. S. Nelson \& M. Olin, eds., Monuments and memory, made and unmade, The University of Chicago Press, Chicago and London, 1-10.

Nolan, D. (21.07.2014) German occupation memorial completed under cover of darkness, Available from: http://budapestbeacon. com/public-policy/german-occupation-memorial-completed-under-cover-of-darkness/ [accessed: 10.08.2014].

Nora, P. (1989) Between memory and history: Les lieux de mémoire, Representations, 26, 7-24. Available from: www.jstor.org/ stable/2928520 [accessed: 10.02.2018]

Palonen, E. (2008) The City-text in Post-communist Budapest: Street names, Memorials, and the Politics of Commemoration, Geojournal, 73(3), 219-230. DOI: 10.1007/s10708-008-9204-2.

Pethő, T. 29.01.2014, Catharsis warded off Controversy over monument of victims of Hungary's German occupation and House of Fates, Available from: http://www.budapesttelegraph.com/ news/627/catharsis_warded_off_controversy_over_monument_of_ victims_of_hungary's_german_occupation_and_house_of_fates [accessed: 10.08.2014].

Proshansky, H., Fabian, A. K. \& Kaminoff, R. (1983) Place identity: Physical world socialization of the self, Journal of Environmental Psychology, 3, 57-83.Un

Rátz, T., Smith, M., \& Michalkó G. (2008) New Places in Old Spaces: Mapping Tourism and Regeneration in Budapest, Tourism Geographies: An International Journal of Tourism Space, Place and Environment, 10 (4), 429-451. DOI: 10.1080/14616680802434064.

Rose-Redwood, R. S. (2008) 'Sixth Avenue is now a memory': Regimes of spatial inscription and the performative limits of the official city-text, Political Geography, 27 (8), 875-894.
Shackely, M. (2001) Managing Sacred Sites: Service Provision and Visitor Experience, Thomson Learning, London.

Shackely, M., ed., (1998) Visitor Management: Case Studies from World Heritage Sites, Butterworth-Heinemann, Oxford.

Shanken, A. M. (2002) Planning Memory: living memorials in theUnited States during World War II, The Art Bulletin, 84(1), 130-147. DOI: $10.1080 / 00043079.2002 .10787014$

Stevens, Q., Franck, K. A., \& Fazakerley, R. (2012) Counter-monuments: the anti-monumental and the dialogic, The Journal of

Architecture, 17 (6), 951-972. DOI: 10.1080/13602365.2012.746035 Strakosch, E. (2010) Counter-monuments and Nation-Building in Australia, Peace Review: A Journal of Social Justice, 22 (3), 268-275. DOI: $10.1080 / 10402659.2010 .502065$

Tölle, A. (2010) Urban identity policies in Berlin: From critical reconstruction to reconstructing, Cities, 27 (5), 348-357. DOI: 10.1016/j.cities.2010.04.005

Ungváry, K., 21.01.2014, Horror alive [Az eleven borzalom]. Available from: http://hvg.hu/velemeny/20140121_Az_eleven_borzalom [accessed: 10.08.2014].

Young, J. E. (1993). The texture of memory: Holocaust memorials and meaning, Yale University Press, New Haven.

Young, J. E. (2000) At memory`s edge, Yale University Press, New Haven and London.

Yurchak, A. (1997) The Cynical Reason of Late Socialism: Power, Pretense, and the Anekdot, Public Culture, 9 (2), 161-188. DOI: 10.1215/08992363-9-2-161.

Verdery, K. (1999) The political life of dead bodies: reburial and post-socialist change, Columbia University Press, New York.

Zeidler, M. (2007) Ideas on Territorial Revision in Hungary 19201945, Social Science Monographs, Wayne, Center for Hungarian Studies and Publications, Institute of Habsburg History, Boulder, Budapest. 